\title{
Safety Assessment and Comparison of Sodium Selenite and Bioselenium Obtained from Yeast in Mice
}

\author{
Xinghua Wang, ${ }^{1}$ Yukun Yang, ${ }^{1}$ Hening Zhang, ${ }^{2}$ and Ju Liu ${ }^{1}$ \\ ${ }^{1}$ School of Life Science, Shanxi University, Taiyuan 030006, China \\ ${ }^{2}$ Institute of Biotechnology, Shanxi University, Taiyuan 030006, China \\ Correspondence should be addressed to Xinghua Wang; xhwang@sxu.edu.cn and Yukun Yang; yangyukun@sxu.edu.cn
}

Received 6 June 2017; Accepted 13 September 2017; Published 30 October 2017

Academic Editor: Yi-Ping Liu

Copyright (c) 2017 Xinghua Wang et al. This is an open access article distributed under the Creative Commons Attribution License, which permits unrestricted use, distribution, and reproduction in any medium, provided the original work is properly cited.

\begin{abstract}
Detailed safety assessment of sodium selenite and bioselenium (bio-Se) was conducted and the results were compared and discussed for the purpose of assessing safety of bio-Se for use in food applications. In this work, acute toxicity studies, micronucleus test, and sperm aberration study in mice, 30-day feeding test of mice, were conducted to evaluate the toxicity of bio-Se obtained from yeast with different fermentation time (transformative time: one month, three months, and six months), and the results were compared with that of inorganic Se (sodium selenite). $\mathrm{LD}_{50}$ of sodium selenite was calculated to be $21.17 \mathrm{mg} / \mathrm{kg}$. $\mathrm{LD}_{50}$ of bio-Se obtained from yeast with different fermentation time was calculated to be $740.2 \mathrm{mg} / \mathrm{kg}, 915.3 \mathrm{mg} / \mathrm{kg}$, and $1179.0 \mathrm{mg} / \mathrm{kg}$, respectively. In the genotoxicity test, bio-Se did not show cytotoxicity and genotoxicity of mice while sodium selenite at all dose groups was significantly different from the negative group. In the 30-day subchronic oral toxicity study, sodium selenite may slow down the growth of the mice and lead to organic damage to some extent. Bio-Se had facilitated effect towards the body weight of the mice and had no significant effect on the shape and function of the important organs of the mice.
\end{abstract}

\section{Introduction}

Selenium (Se) is a naturally occurring metalloid element, which is essential to the health of human and other animals in trace amounts but is harmful in excess. As a micronutrient, Se owns multiple biological functions including regulation of vitamins absorption, participation in electron transfer, body metabolism regulation, affection towards the reproductive function of humans and animals, antitumor, free radical scavenger, antiaging, and antagonism of toxic elements, playing important roles in improvement of the human body's immune system and the prevention of various diseases [14]. Currently, many Se-enriched foods are available in the market, in which Se additives are mainly in the form of inorganic and organic Se. Generally, Se in organic forms has better bioavailability and is less toxic compared with inorganic selenium with poor conversion and high toxicity to some extent [5-8]. Nowadays, various available sources of organic Se, namely, Se-enriched yeast [9-11], selenomethionine [1214], Se-enriched probiotics [15], heterotrophically produced Se-enriched alga $[16,17]$, and Se-enriched plants $[18,19]$, have been investigated over time. Among these organic Se, the main organic Se source used in practice is Se-enriched yeast, in which Se is present predominantly $(94 \pm 5 \%)$ in the form of protein-bound L-selenomethionine [20]. As a kind of organic Se, Se-enriched yeast owned the advantages of high effectiveness, lower toxicity, and better nutrition. However, the composition of the raw products of Se-enriched yeast (obtained by culture and whizzer) is complex and may contain unconverted inorganic selenium, possessing obstacles for the practice application in food industry.

Therefore, in this work, further works were made for the more secure and easily adsorbed bio-Se. The yeast cells were lysed by sonication after a period of growth with sodium selenite and dialyzed to remove the free inorganic selenium. Finally, the bio-Se obtained from yeast was produced. Theoretically, compared with raw products of Se-enriched yeast, bio-Se is a safe and effective formulation which holds important practical value. However, the toxicology of the bioSe obtained from yeast was not fully convinced yet.

Because external intake is the most important source of Se in humans, understanding the toxicity of sodium 
selenite and bio-Se obtained from yeast is the key to the assessment of Se related health risks. In this work, acute toxicity studies, micronucleus test, and sperm aberration study in mice, 30-day subchronic oral toxicity study of mice, were conducted to evaluate the toxicity of bio-Se obtained from yeast with different fermentation time (transformative time: one month, three months, and six months), and the results were compared with that of inorganic Se (sodium selenite). The purpose of this work is to summarize the results obtained from acute toxicity, genetic toxicity, and subchronic toxicity of bio-Se obtained from yeast in mice and compared with the safety assessment of sodium selenite, as well as providing theoretical basis for the application of bioSe obtained from yeast.

\section{Materials and Methods}

2.1. Chemicals and Instruments. Fetal bovine serum (FBS) and Giemsa dye were obtained from Seajet Scientific (Beijing, China) and Zhejiang Tianhang Biotechnology Co., Ltd. (Hangzhou, China), respectively. Other chemicals used in the experiments were purchased from Tianjin Chemical Reagent Research Institute. Se standard solution $(1000 \mu \mathrm{g} / \mathrm{mL})$ was obtained from China Iron and Steel Research Technology Group Co., Ltd. (Beijing, China).

Flame Atomic Absorption Spectrophotometer (FAAS, A6300, Japan Shimadzu Hong Kong Co., Ltd.) equipped with LH-2A Hydride Generator (Brother Chuanghekemao Co., Ltd., Beijing, China) was used for the determination of Se content. JY92-II ultrasonic cell grinder was purchased from Xinzhike Institute (Ningbo, China). Dialysis bag MD34 (8000-14000) was obtained from Sdarbio Life Science Company.

2.2. Preparation Methods of Bio-Se Obtained from Yeast. Bio-Se obtained from yeast was prepared and purified by our laboratory. Cell culture is as follows: yeast strain: Saccharomyces cerevisiae D254; fermentation medium: 2\% glucose, $1 \%$ peptone, $0.5 \%$ yeast extract, $0.1 \% \mathrm{KH}_{2} \mathrm{PO}_{4}, 0.05 \%$ $\mathrm{MgSO}_{4} \cdot 7 \mathrm{H}_{2} \mathrm{O}, 0.01 \% \mathrm{CaCl}_{2} \cdot 6 \mathrm{H}_{2} \mathrm{O}$, and $0.5 \%\left(\mathrm{NH}_{4}\right)_{2} \mathrm{SO}_{4}$. The optimal conditions for $\mathrm{Se}$ accumulation in yeast were optimized using response surface method and were found to be a temperature of $28.6^{\circ} \mathrm{C}, \mathrm{pH}$ value of 6.3 , and an added concentration of $\mathrm{Na}_{2} \mathrm{SeO}_{3}$ of $81.3 \mathrm{mg} / \mathrm{L}$, which resulted in the maximum Se accumulation. Under these conditions, the yield of bio-Se was predicted to be $1544.165 \mu \mathrm{g} / \mathrm{L}$ (using the amount of Se to calculate).

After the yeast cells grew to the required quantity, samples were collected and sonicated, and the lysed cell contents were dialyzed in dialysis bags (MD34) against distilled water with $1 \mathrm{ml}$ of cysteine solution (stock concentration of $150 \mathrm{~g} / \mathrm{L}$ ). During dialysis, the water was consistently changed until the solution did not fade within one minute after the addition of methylene blue, indicating that all the inorganic selenium was eliminated. The selenium incorporation in the extract was measured using FAAS after the extract was digested with mixed acid $\left(\mathrm{HNO}_{3}: \mathrm{HClO}_{4}=4: 1\right)$.
2.3. Animals. Male and female Kunming species of mice were obtained from Experimental Animal Center of Shanxi Medical University (Taiyuan, China). The mice were fasted for $8 \mathrm{~h}$ and with free access to water prior to the experiments. Throughout the experiments, animals were processed according to the suggested ethical guidelines for the care of laboratory animals.

2.4. Acute Toxicity Study of Sodium Selenite and Bio-Se in Mice. The acute toxicity test of sodium selenite and bio-Se in mice was conducted and the results were compared.

60 healthy Kunming mice (6-8-week-old mice, half male and half female) at average body weight (bw) of $18-20 \mathrm{~g}$ were allotted to six groups (each group of ten, half male and half female). The oral dose of sodium selenite experimental group was $5.56,8.33,12.50,18.75,28.12$, and $42.19 \mathrm{mg} / \mathrm{kg}$ bw. After oral administration, the daily behavior, group behavior, toxicity, and death of the mice were observed and recorded for two weeks.

As for bio-Se with different fermentation time, 120 healthy Kunming mice (6-8-week-old mice, half male and half female) at average body weight of 18-20 g were allotted to twelve groups (each group of ten, half male and half female). Acute toxicity of bio-Se with fermentation time of one month, three months, and six months was measured using the oral dose of 5240, 7860, 11790, and $17685 \mathrm{mg} / \mathrm{kg}$ bw. After oral administration, the daily behavior, group behavior, toxicity, and death of the mice were observed and recorded.

2.5. Genetic Toxicity Test of Sodium Selenite and Bio-Se in Mice. Bone marrow micronucleus test and sperm aberration experiment were used to evaluate the genetic toxicity of sodium selenite and bio-Se.

2.5.1. Bone Marrow Micronucleus Test. The experiments were carried out according to Von Ledebur and Schmid [21]. 80 healthy Kunming mice (6-8-week-old mice, half male and half female) at average body weight of 18-20 g were allotted to eight groups. $1 / 2 \mathrm{LD}_{50}, 1 / 4 \mathrm{LD}_{50}$, and $1 / 8 \mathrm{LD}_{50}$ (i.e., 10.59 , 5.29 , and $2.65 \mathrm{mg} / \mathrm{kg} \mathrm{bw}$ ) of sodium selenite were used as high, middle, and low dose group. Bio-Se with fermentation time of six months was used for evaluation. $1 / 2 \mathrm{LD}_{50}, 1 / 4 \mathrm{LD}_{50}$, and $1 / 8 \mathrm{LD}_{50}$ (i.e., $589,2950,1470 \mathrm{mg} / \mathrm{kg}$ bw) were used as high, middle, low dose group. A positive control group (cyclophosphamide, $40 \mathrm{mg} / \mathrm{kg}$ bw) and a negative control group (distilled water) were included.

Sodium selenite or bio-Se was orally administered within $30 \mathrm{~h}$; that is, the interval between the first and the second test was $24 \mathrm{~h}$. After $6 \mathrm{~h}$ of the second test, the tested mice were euthanized by cervical dislocation, and their bone marrow cells were flushed from both femurs into fetal calf serum. After centrifugation, the bone marrow cells were smeared on glass slides, coded for blind analysis, air-dried, and fixed with absolute methanol for $5 \mathrm{~min}$ at room temperature. The smears were stained with Giemsa, dibasic sodium phosphate, and monobasic sodium phosphate to detect micronucleated polychromatic erythrocytes (MNPCE). For each animal, 1000 polychromatic erythrocytes (PCE) were counted to 
TABLE 1: Statistical results of acute toxicity test for sodium selenite.

\begin{tabular}{lcccc}
\hline $\begin{array}{l}\text { Category } \\
(\mathrm{mg} / \mathrm{kg} \mathrm{bw})\end{array}$ & $\begin{array}{c}\text { Number of } \\
\text { tested animals }\end{array}$ & $\begin{array}{c}\text { Number of dead } \\
\text { animals }\end{array}$ & $\begin{array}{c}\text { Number of surviving } \\
\text { animals }\end{array}$ & Mortality (\%) \\
\hline 5.55 & 10 & 0 & 10 & 0 \\
8.33 & 10 & 1 & 9 & 10 \\
12.50 & 10 & 3 & 7 & 30 \\
28.13 & 10 & 8 & 2 & 80 \\
42.19 & 10 & 10 & 0 & 100 \\
\hline
\end{tabular}

determine the frequency of MNPCE using light microscopy. Genetic toxicity and antigenotoxicity were assessed by the frequency of MNPCE, whereas cytotoxicity and anticytotoxicity were evaluated by the PCE and normochromatic erythrocytes (NCE) ratio (PCE/NCE).

To analyze the genotoxic and antigenotoxic activities of sodium selenite or bio-Se using the mouse bone marrow micronucleus test, the frequency of MNPCE in the treated groups was compared to the results obtained from the negative control group using SPSS17.0 software for significant differences analysis $(P \geq 0.05$ indicated no significant difference, $P<0.05$ considered a statistically significant difference).

2.5.2. Sperm Aberration Test. For the sperm aberration test, 80 Kunming male mice were used. Animal grouping and the administered dosages were the same as those in the bone marrow micronucleus test. The mice were intragastrically administered various dosages daily for 5 days and were euthanized by cervical dislocation 35 days after the first administration. The bilateral epididymis was collected, sectioned and stained by routine clinical protocol, and observed under the microscope.

A thousand sperm were observed for each mouse to record the numbers of aberrated sperm, and aberration ratios were analyzed and calculated. Significant differences were analyzed with SPSS software $(P \geq 0.05$ indicated no significant difference, $P<0.05$ considered a statistically significant difference).

2.6. 30-Day Subchronic Oral Toxicity Test. 160 healthy Kunming mice (6 weeks old, half male and half female) at average body weight (bw) of about $16-20 \mathrm{~g}$ were allotted to eight groups (each containing 10 females and 10 males). The highest dose group was set at $20 \%$ of $\mathrm{LD}_{50}$. Three dose groups of sodium selenite were set at $1.41 \mathrm{mg} / \mathrm{kg}, 2.12 \mathrm{mg} / \mathrm{kg}$, and $3.16 \mathrm{mg} / \mathrm{kg}$, and three dose groups of bio-Se were set at $786.3 \mathrm{mg} / \mathrm{kg}, 1179.5 \mathrm{mg} / \mathrm{kg}$, and $1769.3 \mathrm{mg} / \mathrm{kg}$. A control group formed by 20 mice consumed distilled water during a 30-day period.

The daily action, the occurrence of the toxicity, and the death of the mice were observed and recorded daily after the start of the test. At the end of the test, fasting for $12 \mathrm{~h}$ overnight, the mice were euthanized by cervical dislocation. The weights of mice were recorded once a week. The weights of heart, liver, spleen, and kidney were recorded for the calculation of the organ coefficient. SPSS17.0 software was used for significant difference analysis $(P \geq 0.05$ indicated that there was no significant difference, $P<0.05$ considered a statistically significant difference).

\section{Results and Discussion}

3.1. The Acute Toxicity Assay of Sodium Selenite and Bio-Se. To assess the safety of different selenium source (sodium selenite, bio-Se obtained from yeast with different fermentation time (1 month, 3 months, 6 months)), $\mathrm{LD}_{50}$ test was first conducted. After administration of different Se sources, it was found that male and female mice with three dose levels of sodium selenite $(12.50 \mathrm{mg} / \mathrm{kg} \mathrm{bw}, 28.13 \mathrm{mg} / \mathrm{kg}$ bw, $42.19 \mathrm{mg} / \mathrm{kg} \mathrm{bw}$ ) showed convulsion and piloerection and were gathered into piles with varying degrees. Small part of mice showed the symptoms of diarrhea, and all the mice died within one week. At the dose groups of bio-Se with different fermentation time, the tested mice appeared healthy with normal appearance and little mice showed the above phenomenon. The results of acute toxicity test of sodium selenite were shown in Table 1.

Thus, $\mathrm{LD}_{50}$ of sodium selenite was calculated to be $21.17 \mathrm{mg} / \mathrm{kg}$. According to the classification standard of acute toxicity, sodium selenite belongs to the category 5 (highly toxicity). Meanwhile, the acute toxicity test results of bio-Se obtained from yeast were shown in Table 2 .

Thus, $\mathrm{LD}_{50}$ of bio-Se obtained from yeast with different fermentation time (1 month, 3 months, 6 months) was calculated to be $740.2 \mathrm{mg} / \mathrm{kg}, 915.3 \mathrm{mg} / \mathrm{kg}$, and $1179 \mathrm{mg} / \mathrm{kg}$, respectively. According to the classification standard of acute toxicity, bio-Se obtained from yeast with different fermentation time belongs to category 2 (the actual nontoxicity).

$\mathrm{LD}_{50}$ of bio-Se obtained from yeast with different fermentation time was dramatically decreased compared with that of sodium selenite. $\mathrm{LD}_{50}$ of bio-Se obtained from yeast with fermentation time of 6 months even reached $1179 \mathrm{mg} / \mathrm{kg}$. In other words, the toxicity of bio-Se was greatly reduced through biotransformation compared with inorganic selenium. The toxicity of bio-Se could be further reduced as the fermentation time was prolonged. According to the food toxicology measurement index, $\mathrm{LD}_{50}$ should be greater than 10 times the dose which the people may normally be exposed to and then genotoxicity test could be carried next. While bio-Se is considered as selenium supplement, the Se intake of 50 micrograms per day is recommended in China, which was much less than $\mathrm{LD}_{50}$ of bio-Se. So, the next stage of mutagenicity test could be carried out. 
TABLE 2: Statistical results of mortality in acute toxicity test for bio-Se obtained from yeast with different fermentation time.

\begin{tabular}{lcccc}
\hline Category & & \multicolumn{2}{c}{ Mortality (\%) } & \\
& $5240 \mathrm{mg} / \mathrm{kg} \mathrm{bw}$ & $7860 \mathrm{mg} / \mathrm{kg} \mathrm{bw}$ & $11790 \mathrm{mg} / \mathrm{kg} \mathrm{bw}$ & 100 \\
1 \\
1 & 20 & 40 & 80 & 100 \\
2 & 10 & 20 & 30 & 100 \\
3 & 0 & 20 & $\mathrm{mg} / \mathrm{kg} \mathrm{bw}$ \\
\hline
\end{tabular}

Note. 1, 2, and 3 represent the bio-Se obtained from yeast with different fermentation time (1 month, 3 months, 6 months), respectively.

TABLE 3: The experimental results of sodium selenite in bone marrow micronucleus.

\begin{tabular}{|c|c|c|c|c|c|c|}
\hline Category & Dose $(\mathrm{mg} / \mathrm{kg})$ & $\begin{array}{c}\text { Number of tested } \\
\text { animals }\end{array}$ & Check PCE number & MNPCE number & $\begin{array}{l}\text { Micronucleus } \\
\text { rate }(\%))\end{array}$ & $\mathrm{PCE} / \mathrm{NCE}$ \\
\hline $1 / 8 \mathrm{LD}_{50}$ & 2.65 & 10 & $10 \times 1000$ & 93 & $9.30 \pm 0.423^{*}$ & $0.54 \pm 0.25^{*}$ \\
\hline $1 / 4 \mathrm{LD}_{50}$ & 5.29 & 10 & $10 \times 1000$ & 95 & $9.50 \pm 0.696^{*}$ & $0.43 \pm 0.37^{*}$ \\
\hline $1 / 2 \mathrm{LD}_{50}$ & 10.59 & 10 & $10 \times 1000$ & 103 & $10.3 \pm 0.537^{*}$ & $0.16 \pm 0.21^{*}$ \\
\hline $\begin{array}{l}\text { Negative control } \\
\text { group }\end{array}$ & Distilled water & 10 & $10 \times 1000$ & 32 & $3.20 \pm 0.446$ & $1.00 \pm 0.38$ \\
\hline $\begin{array}{l}\text { Positive control } \\
\text { group }\end{array}$ & Cyclophosphamide & 10 & $10 \times 1000$ & 124 & $12.40 \pm 1.511^{*}$ & $0.70 \pm 0.12^{*}$ \\
\hline
\end{tabular}

Note. $*$ indicated that there was a significant difference compared with the negative control group $(P<0.05)$.

TABLE 4: The experimental results of bio-Se in bone marrow micronucleus.

\begin{tabular}{|c|c|c|c|c|c|c|}
\hline Category & Dose $(\mathrm{g} / \mathrm{kg})$ & $\begin{array}{c}\text { Number of tested } \\
\text { animals }\end{array}$ & $\begin{array}{c}\text { Check PCE } \\
\text { number }\end{array}$ & $\begin{array}{l}\text { MNPCE } \\
\text { number }\end{array}$ & $\begin{array}{l}\text { Micronucleus } \\
\text { rate }(\%)\end{array}$ & $\mathrm{PCE} / \mathrm{NCE}$ \\
\hline $1 / 8 \mathrm{LD}_{50}$ & 1.47 & 10 & $10 \times 1000$ & 28 & $2.80 \pm 0.493$ & $1.08 \pm 0.34$ \\
\hline $1 / 4 \mathrm{LD}_{50}$ & 2.95 & 10 & $10 \times 1000$ & 34 & $3.40 \pm 0.424$ & $1.09 \pm 0.41$ \\
\hline $1 / 2 \mathrm{LD}_{50}$ & 5.89 & 10 & $10 \times 1000$ & 32 & $3.20 \pm 0.437$ & $1.00 \pm 0.60$ \\
\hline $\begin{array}{l}\text { Negative control } \\
\text { group }\end{array}$ & Distilled water & 10 & $10 \times 1000$ & 32 & $3.20 \pm 0.557$ & $0.90 \pm 0.29$ \\
\hline Positive control group & Cyclophosphamide & 10 & $10 \times 1000$ & 124 & $12.40 \pm 1.459^{*}$ & $0.74 \pm 0.17^{*}$ \\
\hline
\end{tabular}

Note. $*$ indicates that there were significant differences with the negative control group $(P<0.05)$.

\subsection{Genetic Toxicity Test of Sodium Selenite and Bio-Se}

3.2.1. Bone Marrow Micronucleus Test of Sodium Selenite and Bio-Se. Tables 3 and 4 showed the results of cytotoxic and genotoxic activities in the bone marrow of mice treated with sodium selenite and bio-Se based on micronucleus rate and polychromatic erythrocyte/normochromatic erythrocyte (PCE/NCE) ratio. As expected, the negative control group (distilled water) exhibited low micronucleus rate level, whereas the positive control group of micronucleus rate was significantly higher than the negative control group $(P<$ 0.05 ), indicating that the experimental system is sensitive to the mutation.

According to Table 3, the groups which received $1 / 8 \mathrm{LD}_{50}$, $1 / 4 \mathrm{LD}_{50}$, and $1 / 2 \mathrm{LD}_{50}$ amount of sodium selenite exhibited mean micronucleus rate of $9.3,9.5$, and $10.3 \%$, respectively (the negative control group exhibited mean micronucleus rate of $3.2 \%$ ). At all tested doses, sodium selenite caused significant increase in the micronucleus rate compared to the negative control group $(P<0.05)$. Meanwhile, PCE/NCE ratio of sodium selenite was $0.54,0.43$, and 0.16 , respectively, which were significantly different compared with the negative control group, and its value was not in the normal range (0.6 1.2 belong to the normal range, $<0.6$ represents that formation of PCE was inhibited). In the bone marrow micronucleus test, sodium selenite could increase the micronucleus rate of bone marrow cells in mice, indicating that sodium selenite had mutagenicity.

According to Table 4, the micronucleus rates of the three dose groups of bio-Se were not significantly different from that of the negative control group, while the result of PCE/NCE ratio in the three dose groups of bio-Se was not significantly different from that of the negative control group $(P>0.05)$.

In the experiment, the ratio of PCE/NCE of bio-Se groups was in the normal range, proving bio-Se does not have the role of cell chromosome mutation. From the experimental results of bone marrow micronucleus test, it could be concluded that the mutagenicity of bio-Se obtained from yeast on mice decreased significantly compared with sodium selenite groups. 
TABLE 5: The experimental results of sodium selenite in sperm aberration test.

\begin{tabular}{|c|c|c|c|c|c|}
\hline Category & Dose (mg/kg) & $\begin{array}{c}\text { Number of tested } \\
\text { animals }\end{array}$ & Sperm count & $\begin{array}{l}\text { Distorted sperm } \\
\text { count }\end{array}$ & $\begin{array}{c}\text { Sperm } \\
\text { aberration rate } \\
(\%)\end{array}$ \\
\hline $1 / 2 \mathrm{LD}_{50}$ & 10.59 & 10 & $10 \times 1000$ & 395 & $3.95 \pm 0.443^{*}$ \\
\hline $1 / 4 \mathrm{LD}_{50}$ & 5.29 & 10 & $10 \times 1000$ & 404 & $4.04 \pm 0.428^{*}$ \\
\hline $1 / 2 \mathrm{LD}_{50}$ & 2.65 & 10 & $10 \times 1000$ & 420 & $4.20 \pm 0.561^{*}$ \\
\hline $\begin{array}{l}\text { Negative control } \\
\text { group }\end{array}$ & Distilled water & 10 & $10 \times 1000$ & 269 & $2.69 \pm 0.658$ \\
\hline $\begin{array}{l}\text { Positive control } \\
\text { group }\end{array}$ & $\begin{array}{c}\text { Cyclophosphamide } \\
\text { (40 mg/kg) }\end{array}$ & 10 & $10 \times 1000$ & 445 & $4.45 \pm 1.516^{*}$ \\
\hline
\end{tabular}

Note. $*$ indicates that there is a significant difference compared with the negative control group $(P<0.05)$.

TABLE 6: The experimental results of bio-Se in sperm aberration test.

\begin{tabular}{|c|c|c|c|c|c|}
\hline Category & Dose (mg/kg) & $\begin{array}{l}\text { Number of tested } \\
\text { animals }\end{array}$ & Sperm count & $\begin{array}{l}\text { Distortion sperm } \\
\text { count }\end{array}$ & $\begin{array}{c}\text { Sperm } \\
\text { aberration rate } \\
(\%)\end{array}$ \\
\hline $1 / 2 \mathrm{LD}_{50}$ & 1.47 & 10 & $10 \times 1000$ & 243 & $2.43 \pm 0.532$ \\
\hline $1 / 4 \mathrm{LD}_{50}$ & 2.95 & 10 & $10 \times 1000$ & 283 & $2.83 \pm 0.547$ \\
\hline $1 / 2 \mathrm{LD}_{50}$ & 5.89 & 10 & $10 \times 1000$ & 252 & $2.52 \pm 0.475$ \\
\hline $\begin{array}{l}\text { Negative control } \\
\text { group }\end{array}$ & Distilled water & 10 & $10 \times 1000$ & 269 & $2.69 \pm 0.658$ \\
\hline $\begin{array}{l}\text { Positive control } \\
\text { group }\end{array}$ & $\begin{array}{l}\text { Cyclophosphamide } \\
(40 \mathrm{mg} / \mathrm{kg})\end{array}$ & 10 & $10 \times 1000$ & 445 & $4.45 \pm 1.158^{*}$ \\
\hline
\end{tabular}

Note. $*$ indicates that there are significant differences $(P<0.05)$ with negative control group.

3.2.2. Sperm Aberration Test of Sodium Selenite and Bio$\mathrm{Se}$. From Table 5, the sperm aberration rate of the positive control group was significantly higher than that of the negative control group $(P<0.05)$, indicating that the experimental system was sensitive to the mutagenicity. Sperm aberration rates in three dose groups of sodium selenite were significantly different from that of the negative control group $(P<0.05)$, indicating that sodium selenite could induce mouse sperm more prone to distortion and thus lead to the rising of sperm aberration rate.

From Table 6, the sperm aberration rate of the positive control group was significantly higher than that of the negative control group $(P<0.05)$, indicating that the experimental system was sensitive to the mutagenicity. Sperm aberration rate in the three groups of bio-Se has no significant difference compared with the negative control group $(P>$ $0.05)$, indicating that bio-Se could not cause sperm squirrel distortion of mice.

Therefore, the results indicated that sodium selenite existed genetic toxicity, while bio-Se did not cause mutagenic effects on mouse cells.

3.3. Subchronic Toxicity Test of Sodium Selenite and Bio-Se. The 30-day subchronic toxicity test was conducted after 30 days of continuous administration of the test animals for a more profound understanding of the toxicological properties of sodium selenite and bio-Se.
3.3.1. General Behavior Observation. During the experiment, it was observed that the mice in the high dose group of sodium selenite had a decrease in activity compared with the negative control group. There was no significant general behavioral difference observed between control group and other groups (middle, low dose group of sodium selenite, and three groups of bio-Se).

3.3.2. Effects of Sodium Selenite and Bio-Se on Body Weight of Mice. The effect of sodium selenite and the bio-Se groups on body weight of mice was recorded and the results were shown in Tables 7 and 8.

As shown in the Table 7 the weekly body weight gains of mice in sodium selenite groups were lower than that of the negative group starting from the second week, indicating that sodium selenite may have inhibition effect on the mice growth. According to the data analysis, there was significant difference between the three dose groups and the negative control group at the third week, and there was highly significant difference between the high dose group and the negative control group at the fourth week. It should be noted that there was a significant difference between the low dose group and the negative control group at the second week. While other groups did not show significant difference, the probable reason was that effect of Se with different concentrations on the growth was different. This means that 
TABLE 7: Effects of sodium selenite on body weight using 30-day feeding experiment.

\begin{tabular}{|c|c|c|c|c|c|}
\hline \multirow[b]{2}{*}{ Group } & \multicolumn{4}{|c|}{ Average weight (g) } & \multirow[b]{2}{*}{$\begin{array}{c}4 \text { weeks } \\
(\text { mean } \pm \mathrm{SD})\end{array}$} \\
\hline & $\begin{array}{l}\text { Prior to the } \\
\text { experiment }\end{array}$ & $\begin{array}{c}1 \text { week } \\
(\text { mean } \pm S D)\end{array}$ & $\begin{array}{c}2 \text { weeks } \\
(\text { mean } \pm S D)\end{array}$ & $\begin{array}{c}3 \text { weeks } \\
(\text { mean } \pm S D)\end{array}$ & \\
\hline Negative control & $16.51 \pm 0.97^{\mathrm{A}}$ & $22.53 \pm 4.47^{\mathrm{A}}$ & $26.53 \pm 3.24^{\mathrm{A}}$ & $29.41 \pm 3.34^{\mathrm{A}}$ & $35.42 \pm 2.67^{\mathrm{A}}$ \\
\hline Low dose group & $16.82 \pm 1.42^{\mathrm{A}}$ & $23.71 \pm 2.06^{\mathrm{A}}$ & $23.36 \pm 1.69^{\mathrm{a}}$ & $23.32 \pm 1.69^{\mathrm{a}}$ & $22.71 \pm 2.66^{\mathrm{B}}$ \\
\hline Middle dose group & $16.81 \pm 1.52^{\mathrm{A}}$ & $22.43 \pm 2.60^{\mathrm{A}}$ & $24.74 \pm 2.34^{\mathrm{A}}$ & $21.33 \pm 2.49^{\mathrm{b}}$ & $24.81 \pm 2.31^{\mathrm{b}}$ \\
\hline High dose group & $17.01 \pm 1.45^{\mathrm{A}}$ & $24.30 \pm 2.98^{\mathrm{A}}$ & $24.52 \pm 2.78^{\mathrm{A}}$ & $23.40 \pm 2.41^{\mathrm{a}}$ & $23.11 \pm 2.84^{\mathrm{B}}$ \\
\hline
\end{tabular}

Note. ${ }^{\mathrm{a}, \mathrm{b}, \mathrm{c}, \mathrm{d}, \mathrm{A}, \mathrm{B}}$ Letters in common in the same column do not present significant difference $(P>0.05)$, for example, $\mathrm{A}$ and $\mathrm{A}, \mathrm{b}$ and $\mathrm{b}$. Same letters in uppercase and lowercase or different letters in lowercase in the same column present significant difference $(P<0.05)$, for example, B and b, a and $c$. Different letters in uppercase or different letter in uppercase and lowercase present extremely significant difference, for example, A and B, A and b.

TABLE 8: Effects of bio-Se on body weight using 30-day feeding experiment.

\begin{tabular}{|c|c|c|c|c|c|}
\hline \multirow[b]{2}{*}{ Group } & \multicolumn{5}{|c|}{ Average weight (g) } \\
\hline & $\begin{array}{l}\text { Prior to the } \\
\text { experiment }\end{array}$ & $\begin{array}{c}1 \text { week } \\
(\text { mean } \pm S D)\end{array}$ & $\begin{array}{c}2 \text { weeks } \\
(\text { mean } \pm S D)\end{array}$ & $\begin{array}{c}3 \text { weeks } \\
(\text { mean } \pm S D)\end{array}$ & $\begin{array}{c}4 \text { weeks } \\
(\text { mean } \pm S D)\end{array}$ \\
\hline Negative control & $19.96 \pm 1.46^{\mathrm{A}}$ & $24.72 \pm 2.29^{A}$ & $26.86 \pm 2.37^{\mathrm{A}}$ & $28.71 \pm 2.66^{\mathrm{A}}$ & $29.86 \pm 2.52^{\mathrm{A}}$ \\
\hline Low dose group & $19.77 \pm 1.77^{\mathrm{A}}$ & $25.01 \pm 2.68^{A}$ & $27.30 \pm 3.27^{\mathrm{A}}$ & $29.50 \pm 3.32^{\mathrm{A}}$ & $30.43 \pm 3.37^{\mathrm{A}}$ \\
\hline $\begin{array}{l}\text { Middle dose } \\
\text { group }\end{array}$ & $19.85 \pm 1.77^{\mathrm{A}}$ & $25.78 \pm 2.97^{A}$ & $28.77 \pm 3.21^{\mathrm{A}}$ & $30.75 \pm 3.06^{\mathrm{A}}$ & $31.78 \pm 3.10^{\mathrm{A}}$ \\
\hline High dose group & $20.25 \pm 1.63^{\mathrm{A}}$ & $25.32 \pm 2.89^{\mathrm{A}}$ & $28.04 \pm 3.27^{\mathrm{A}}$ & $31.16 \pm 3.24^{\mathrm{B}}$ & $33.65 \pm 3.40^{\mathrm{B}}$ \\
\hline
\end{tabular}

TABLE 9: Effects of 30-day subchronic toxicity test on organ coefficient of mice using sodium selenite.

\begin{tabular}{|c|c|c|c|c|}
\hline Group & $\begin{array}{l}\text { Heart/bw\% } \\
(\text { mean } \pm \mathrm{SD})\end{array}$ & $\begin{array}{c}\text { Liver/bw\% } \\
(\text { mean } \pm S D)\end{array}$ & $\begin{array}{l}\text { Spleen/bw\% } \\
(\text { mean } \pm S D)\end{array}$ & $\begin{array}{l}\text { Kidney/bw\% } \\
(\text { mean } \pm \text { SD) }\end{array}$ \\
\hline Negative control & $0.35 \pm 0.05^{\mathrm{b}}$ & $4.36 \pm 0.38^{\mathrm{b}}$ & $0.23 \pm 0.03^{\mathrm{a}}$ & $0.68 \pm 0.05^{\mathrm{c}}$ \\
\hline Low dose group & $0.36 \pm 0.03^{\mathrm{b}}$ & $4.70 \pm 0.38^{\mathrm{b}}$ & $0.22 \pm 0.02^{\mathrm{B}}$ & $0.71 \pm 0.06^{\mathrm{b}}$ \\
\hline Middle dose group & $0.39 \pm 0.04^{\mathrm{a}}$ & $5.03 \pm 0.62^{\mathrm{A}}$ & $0.19 \pm 0.01^{\mathrm{a}}$ & $0.74 \pm 0.04^{\mathrm{B}}$ \\
\hline High dose group & $0.43 \pm 0.06^{\mathrm{A}}$ & $5.41 \pm 0.78^{\mathrm{b}}$ & $0.16 \pm 0.01^{\mathrm{B}}$ & $0.79 \pm 0.07^{\mathrm{A}}$ \\
\hline
\end{tabular}

only the concentration of the test substance at a certain range could play an obvious effect on the results.

As shown in Table 8, the weight of the mice in the high, middle, and low groups of bio-Se during the 30-day test period was increasing continuously. Compared with the negative control group, there was no significant difference in the weight of low and middle dose group, while in the high dose group at third and fourth week, there was significant difference in the weight gain compared with control group.

Through the experimental results of weight changes, it could be concluded that bio-Se had weight gain effect on the growth of the mice compared with the inhibition effect on the mice growth of sodium selenite. There was no significant negative effect, and the body weight of the mice in the high dose group of bio-Se was significantly increased compared with the negative control group.
3.3.3. Effects of 30-Day Subchronic Toxicity Test on Organ Coefficient of Mice Using Sodium Selenite and Bio-Se. The organ coefficient is a good way to express the toxicological properties of the test substance towards organ, which could explain that the pathology of the tissue has changed. When the organ coefficient decreases, this decrease indicates the atrophy and degeneration of the organ, while the increment of organ coefficient indicates that the organ had hypertrophy or other lesions.

Effects of 30-day subchronic toxicity test on organ coefficient (organ-to-body weight ratio) of mice using sodium selenite and bio-Se were shown in Tables 9 and 10. According to the data from Table 9, the organ coefficients of heart, spleen, and kidney in high dose group had highly significant difference $(P<0.01)$ compared with control group. In the low and middle dose groups, there was significant 
TABLE 10: Effects of 30-day feeding test on organ coefficient of mice using bio-Se.

\begin{tabular}{lcccc}
\hline Group & $\begin{array}{c}\text { Heart/bw\% } \\
(\mathrm{mean} \pm \mathrm{SD})\end{array}$ & $\begin{array}{c}\text { Liver/bw\% } \\
(\text { mean } \pm \text { SD })\end{array}$ & $\begin{array}{c}\text { Spleen/bw\% } \\
(\text { mean } \pm \text { SD })\end{array}$ & $\begin{array}{c}\text { Kidney/bw\% } \\
(\mathrm{mean} \pm \mathrm{SD})\end{array}$ \\
\hline Negative control & $0.53 \pm 0.04$ & $4.78 \pm 0.33$ & $0.37 \pm 0.04$ & $1.39 \pm 0.12$ \\
Low dose group & $0.54 \pm 0.04$ & $4.73 \pm 0.25$ & $0.38 \pm 0.04$ & $1.42 \pm 0.14$ \\
Middle dose group & $0.51 \pm 0.03$ & $4.95 \pm 0.40$ & $0.35 \pm 0.04$ & $1.38 \pm 0.13$ \\
High dose group & $0.49 \pm 0.05$ & $4.63 \pm 0.39$ & $0.36 \pm 0.06$ & $1.39 \pm 0.14$ \\
\hline
\end{tabular}

difference or highly significant difference in different organ coefficients compared with the control group. The liver and kidney were heavier after the intake of excess sodium selenite, and the synthesis function of liver albumin decreased or albumin precipitated between cells and cells, resulting in decreased plasma osmotic pressure, and thus liver and kidney cells were swollen. Spleen coefficient was lower than the negative control group, indicating that the spleen had a small degree of atrophy. The reason may be that sodium selenite had inhibited the growth of spleen. It was observed that there was damage of heart, liver, spleen, and kidney after the anatomy.

The effect of 30-day subchronic toxicity test using bio-Se on the organ coefficient of the mice was shown in Table 10. The organ coefficient of heart, liver, spleen, and kidney in three doses groups had no statistical difference $(P>$ $0.05)$ when compared with the control group. There was no abnormal change in the main organs after the anatomy of mice. Therefore, it could be concluded that the bio-Se has no significant effect on the shape and function of the organs of the important organs of the mice. After fermenting process of yeast, the toxicity of bio-Se was significantly lower than that of sodium selenite, which laid the foundation for subsequent food application.

\section{Conclusion}

Detailed safety assessment of sodium selenite and bio-Se was conducted and the results were compared and discussed in this work. In conclusion, in the acute toxicity test, $\mathrm{LD}_{50}$ of sodium selenite was calculated to be $21.17 \mathrm{mg} / \mathrm{kg}$. $\mathrm{LD}_{50}$ of bio-Se obtained from yeast with different fermentation time (1 month, 3 months, 6 months) was calculated to be $0.7402 \mathrm{~g} / \mathrm{kg}, 0.9153 \mathrm{~g} / \mathrm{kg}$, and $1.179 \mathrm{~g} / \mathrm{kg}$, respectively. In the genotoxicity test, micronucleus rate (\%o), PCE/NCE, and sperm aberration rate (\%) of sodium selenite at all dose groups were significantly different from the negative group, while bio-Se did not have significant difference with the negative group. In the 30-day subchronic oral toxicity study, sodium selenite may slow down the growth of rats and lead to organic damage to some extent. Bio-Se had facilitated effect towards the body weight of the mice and had no significant effect on the shape and function of the important organs of the mice. Therefore, from the results of the study presented herein, it may be concluded that bio-Se obtained from yeast after fermentation and transformation of sodium selenite had no significant toxicity and could be considered safe.

\section{Conflicts of Interest}

The authors declare that there are no conflicts of interest.

\section{Acknowledgments}

This work was supported by the project of Shanxi Science and Technology Department (Project no. 20140311021-5), the National Science Foundation of China (Project no. 31701686), the Youth Science and Technology Research Fund of Shanxi Province, China (Project no. 201701D221180), and the Fund for the Start-Up of Talents of Shanxi (Project no. 113546008).

\section{References}

[1] K. M. Brown and J. R. Arthur, "Selenium, selenoproteins and human health: a review," Public Health Nutrition, vol. 4, no. 2, pp. 593-599, 2001.

[2] J. Kohrle, R. Brigelius-Flohe, A. Bock, R. Gartner, O. Meyer, and L. Flohe, "Selenium in biology: Facts and medical perspectives," biological chemistry, vol. 381, no. 9-10, pp. 849-864, 2000.

[3] T. Li, T. He, X. Tan et al., "Prevalence of age-related cataract in high-selenium areas of China," Biological Trace Element Research, vol. 128, no. 1, pp. 1-7, 2009.

[4] L. Y. Zhao, S. Q. Xu, R. Q. Zhao, Z. Q. Peng, and X. J. Pan, "Effects of selenium and methionine supplementation of breeder hen diets on selenium concentration and oxidative stability of lipids in the thigh muscles of progeny," Journal of Food Science, vol. 74, no. 7, pp. C569-C574, 2009.

[5] F. A. Soares, M. Farina, A. C. Böettcher, A. L. Braga, and J. B. T. Rocha, "Organic and inorganic forms of selenium inhibited differently fish (Rhamdia quelen) and rat (Rattus norvergicus albinus) $\delta$-aminolevulinate dehydratase," Environmental Research, vol. 98, no. 1, pp. 46-54, 2005.

[6] H. Liu, L. Wen, H. Tan, Z. Cheng, and Z. Tan, Research Progress on Pharmacological Activity of Selenium Polysaccharide, China Pharmaceuticals, 2010.

[7] X. Sheng and S. G. Yu, "Research on organic selenium accumulation of Ganoderma lucidum cultured in lanthanidecontaining liquid," Southwest China Journal of Agricultural Sciences, vol. 21, pp. 1654-1657, 2008.

[8] S. Zhao, "Research progress of yeast selenium in swine's nutrition," Anhui Agricultural Science Bulletin, vol. 17, p. 116, 2013.

[9] M. Baylan, S. Canogullari, T. Ayasan, and G. Copur, "Effects of dietary selenium source, storage time, and temperature on the quality of quail eggs," Biological Trace Element Research, vol. 143, no. 2, pp. 957-964, 2011.

[10] E. Delezie, M. Rovers, A. Van Der Aa, A. Ruttens, S. Wittocx, and L. Segers, "Comparing responses to different selenium 
sources and dosages in laying hens," Poultry Science, vol. 93, no. 12, pp. 3083-3090, 2014.

[11] G. Invernizzi, A. Agazzi, M. Ferroni et al., "Effects of inclusion of selenium-enriched yeast in the diet of laying hens on performance, eggshell quality, and selenium tissue deposition," Italian Journal of Animal Science, vol. 12, no. 1, pp. 1-8, 2012.

[12] C. L. Jing, X. F. Dong, Z. M. Wang, S. Liu, and J. M. Tong, "Comparative study of DL-selenomethionine vs sodium selenite and seleno-yeast on antioxidant activity and selenium status in laying hens," Poultry Science, vol. 94, no. 5, pp. 965-975, 2015.

[13] R. N. Reis, S. L. Vieira, P. C. Nascimento, J. E. Peña, R. Barros, and C. A. Torres, "Selenium contents of eggs from broiler breeders supplemented with sodium selenite or zinc-Lselenium-methionine," Journal of Applied Poultry Research, vol. 18, no. 2, pp. 151-157, 2009.

[14] R. Wu, X. Zhan, Y. Wang, X. Zhang, M. Wang, and D. Yuan, "Effect of different selemethionine forms and levels on performance of breeder hens and se distribution of tissue and egg inclusion," Biological Trace Element Research, vol. 143, no. 2, pp. 923-931, 2011.

[15] C. Pan, Y. Zhao, S. F. Liao et al., "Effect of selenium-enriched probiotics on laying performance, egg quality, egg selenium content, and egg glutathione peroxidase activity," Journal of Agricultural and Food Chemistry, vol. 59, no. 21, pp. 11424-11431, 2011.

[16] J. Doucha, K. Lívanský, V. Kotrbáček, and V. Zachleder, "Production of Chlorella biomass enriched by selenium and its use in animal nutrition: A review," Applied Microbiology and Biotechnology, vol. 83, no. 6, pp. 1001-1008, 2009.

[17] M. Skřivan, V. Skřivanová, G. Dlouhá, I. Brányiková, V. Zachleder, and M. Vítová, "The use of selenium-enriched alga Scenedesmus quadricauda in a chicken diet," Czech Journal of Animal Science, vol. 55, no. 12, pp. 565-571, 2010.

[18] O. Chinrasri, P. Chantiratikul, W. Thosaikham et al., "Effect of selenium-enriched bean sprout and other selenium sources on productivity and selenium concentration in eggs of laying hens," Asian-Australasian Journal of Animal Sciences, vol. 22, no. 12, pp. 1661-1666, 2009.

[19] T. C. Seo, J. E. Spallholz, H. K. Yun, and S. W. Kim, "Seleniumenriched garlic and cabbage as a dietary selenium source for broilers," Journal of Medicinal Food, vol. 11, no. 4, pp. 687-692, 2008.

[20] S. Qin, K. Huang, J. Gao, D. Huang, T. Cai, and C. Pan, "Comparison of glutathione peroxidase 1 and iodothyronine deiodinase 1 mRNA expression in murine liver after feeding selenite or selenized yeast," Journal of Trace Elements in Medicine and Biology, vol. 23, no. 1, pp. 29-35, 2009.

[21] M. Von Ledebur and W. Schmid, "The micronucleus test methodological aspects," Mutation Research - Fundamental and Molecular Mechanisms of Mutagenesis, vol. 19, no. 1, pp. 109-117, 1973. 

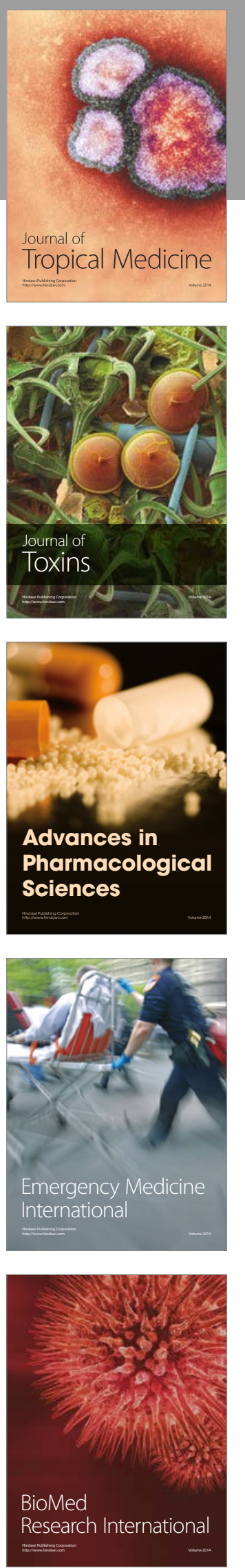
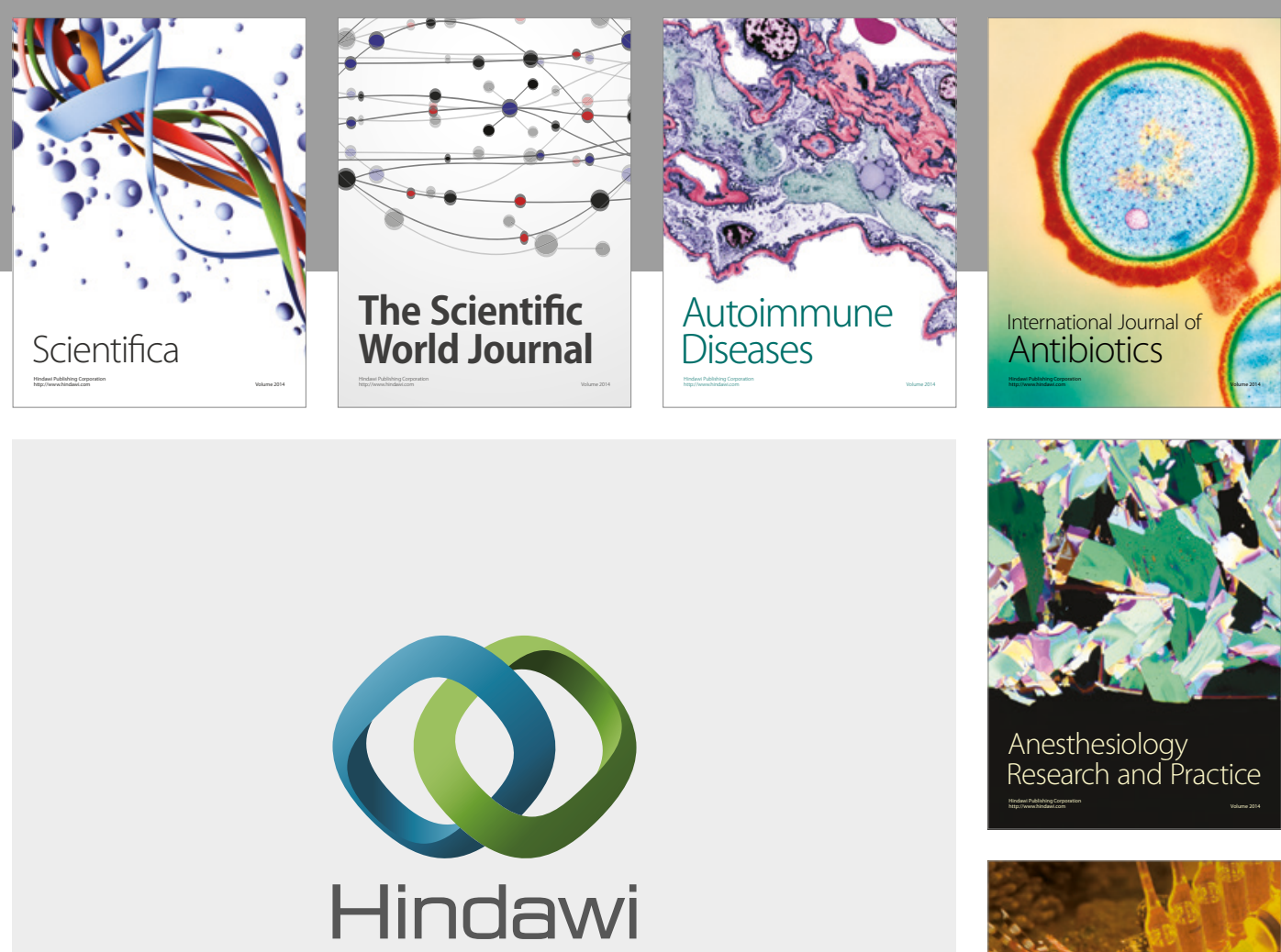

Submit your manuscripts at

https://www.hindawi.com
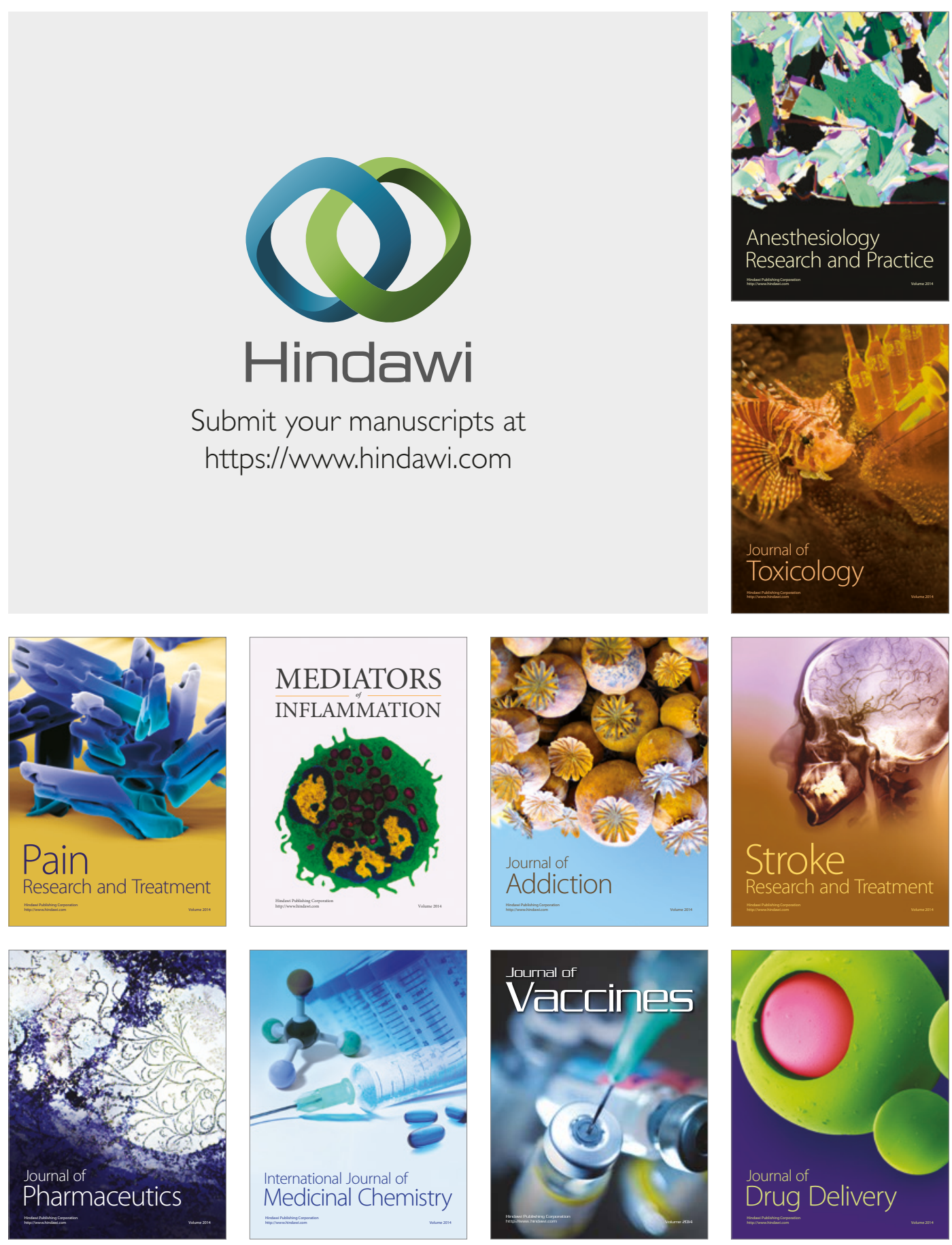